\title{
ACTIVATING STUDENTS' MULTIPLE INTELLIGENCES IN SPEAKING ACTIVITIES
}

\author{
M. Tolkhah Adityas \\ Ahmad Dahlan University Yogyakarta \\ aditboma@gmail.com
}

\begin{abstract}
Language competence can be achieved by developing students' intelligences. However, the fact that students' potentials and intelligences vary has often been ignored. Appropriate learning activities are therefore needed to help students optimize such intelligences. This article aims at discussing how language teachers contribute to the enhancement of Multiple Intelligences in foreign language teaching, particularly in speaking classes. The paper also reviews the types of intelligences defined by Howard Gardner and proponents of this theory in terms of language teaching as well as exemplifies pedagogical methodologies by which students' multiple inttelligence can be activated in speaking activities.
\end{abstract}

Keywords: multiple intelligences, language teaching, language learning

\section{INTRODUCTION}

It is believed that the implementation of Multiple Intelligences Theory has important impact on English language teaching and learning, and can be considered valuable for both teachers and students as well as for the curriculum, instructional strategies, materials, and activities. Gage and Berlier (1988) in Fajar (n.d.) views intelligence as one's ability to solve problems that typically uses abstraction and general knowledge gained from informal interaction with the environment. Students' intelligences vary; therefore, they need to be developed.

However, current pedagogical practices have tended to overemphasize the importance of optimizing Intelligent Quotient. Muslich (2011) also maintains the current education emphasizes too much on the aspects of knowledge, and therefore, is less able to develop values, attitudes, and character.

In many educational contexts, learners have often been considered successful and intelligent on account of their high IQ test or grades. However, in many cases, people with high IQ do not always succeed whereas those with moderate IQ are more successful in life

Mulyadi (2002) also concedes that it is academically inappropriate to use logic as the only measurement of ability; Rather, one's overall competence should be considered from other aspects of intelligences. This system exactly needs to be fixed. Education should not only look at a person's intelligence based on IQ or 
grades, but also should consider multiple intelligences as a basis to assess ability. Basically, no student is stupid; every student has the potential and uniqueness.

A number of studies have been conducted to investigate the application of the theory in English classes. Christison as cited in Ibragimova (2011) suggests teachers identify and categorize activities in their classes, and presents four stages of how MI-based lesson can be reinforced: arouse the intelligence, improve and support it, organize lessons according to different intelligence types and integrate intelligences into problem solving. Akbari and Hosseini (2007) focused on possible connection between the use of language learning strategies and the scores of multiple intelligences among the foreign language learners of English. The results revealed that there were significant correlations between the learners" use of language strategies and IQ scores. More specifically, the analysis indicated that musical intelligence had no correlation with any of the strategies, whereas, kinesthetic intelligence correlated with only memory learning strategies

The optimization of multiple intelligences in speaking classes can be done through creative and innovative learning activities which would optimally develop students' potentials and meet their needs. They will learn a variety of activities that highlight the aspects of intelligence.

\section{DISCUSSION}

\section{Multiple Intelligences}

The concept of multiple intelligences was first introduced by Howard Garner in 1983. He proposes 8 types of intelligence that can be used to measure a person's intelligence; they are mathematical logic, linguistic, musical, visual-spatial, kinesthetic, interpersonal, intrapersonal, and naturalist. Furthermore, Armstrong (2002) in his book adds one more intelligence called existentialist intelligence. Each type of intelligences has a specification and is explained as follows:

1. Linguistic intelligence

Linguistic intelligence is the ability to use words effectively, either to influence or to manipulate. In everyday life linguistic is useful for talking, listening, reading, and writing. In terms of foreign or second language learning classrooms, it can be noted that students with strong linguistic intelligence can easily express themselves in a spoken or written manner, can easily match synonyms, comprehend a reading text or write a paragraph.

2. Logical-Mathematical Intelligence

Logical-mathematical intelligence involves skill or proficiency in numbers, logic and common sense. In everyday life this intelligence is used to analyze financial statements, understand the calculation of the national debt, or ingestion of a research report. Students who have this ability in the context of foreign language learning, can sequence described events in a chronological order, classify language items easily, or successfully manage to work on problemsolving activities.

3. Spatial intelligence

Spatial intelligence involves a person's ability to visualize images inside (imagination) or create it in the form of two- or three -dimensions. The examples 
of this intelligence in everyday life include decorating the house, garden designing, drawing or painting, and art work. In language classes, teachers can vary different tasks such as pictures, concept mapping or diagrams to successfully help the students who possess visual-spatial intelligence.

4. Kinesthetic Intelligence

Kinesthetic intelligence is the intelligence of the entire body and also the intelligence of the hand. In the everyday life we utilize this intelligent in such activities as opening a bottle cap, installing the lights in the house, repairing cars, sports, dancing, etc. Students whose strong intelligence is bodily kinesthetic learn foreign languages effectively through games, miming out different actions, drama, role plays and other activities which require bodily movements.

5. Musical Intelligence

Musical intelligence involves the ability to sing a song, remember the melody of music, have a sense of rhythm, or just enjoy the music. In everyday life, we benefit from this intelligence in many ways, for example: when we sing, play musical instruments, enjoy music on TV / radio, etc. Foreign language learners with this particular type of intelligence can be fostered by using music, songs or rhymes.

6. Interpersonal Intelligence

Interpersonal intelligence involves the ability to understand and work with others. In everyday life, whether for personal, family, and work, this intelligence is considered absolutely necessary - and is often referred to as the "more important" than the other intelligence to be successful in life. Interpersonal intelligence involves many things, for example: the ability to empathize, the ability to manipulate, the ability to "read people", and the ability to make friends. In a language learning classroom, learners who posess this type of intelligence excel in analyzing characters, retelling stories from different points of view or discussing different opinions.

7. Intrapersonal Intelligence

Intrapersonal intelligence is the intelligence possessed by a person to understand his/herself, the intelligence to know "who I am" to know "what my strengths and weaknesses are". Foreign language learners with predominant intrapersonal experience excel in activities which require self analysis. For instance, writing reflections or journal keeping can effectively cater for this type of intelligence.

8. Naturalist Intelligence

Naturalist intelligence involves the ability to recognize the natural forms around us. In daily life we need the intelligence for gardening, camping, or doing ecological projects. In language learning, teachers can give the form of natural and environmental concepts and materials, and classify activities in the form of sounds created in the natural world.

9. Existentialist intelligence

Existential intelligence is one's ability to answer the deepest problems of human existence and whereabouts. People with this intelligence are those who always 
question everything about nature and the role of self-existence in nature. The jobs that require this type of intelligence are philosopher and theologian.

\section{Integrating Multiple Intelligence in Speaking Activities}

The optimization of multiple intelligences in speaking classes can be achieved through creative and innovative learning activities. Learning materials can be combined in a single theme presented by taking into account student characteristics such as interests, talents, and intelligence, so that every student has the opportunity to succeed according to his or her strengths.

According to Trianto (2011), multiple intelligences can be best applied based on the following three principles. They are:

1. Planning Phase that covers: a) determining the types of subjects, b) choosing materials related to competence standards and basic competence, c) determining intelligence to develop, d) formulating indicators of learning outcomes, e) preparing a syllabus and lesson plan.

2. Implementation phase that involves the three principles that must be taken into consideration in the implementation of thematic learning. They are a) the teacher should not dominate the learning activities, but acts as a mentor and facilitator, b) the teacher clearly explains the responsibilities for both individuals and groups in any given task, and c) the teacher should be able to accommodate the students' ideas that sometimes are not in the lesson plan.

3. Assessment and evaluation phase that is continuously and thoroughly conducted in both the process and the learning outcomes. It is used as a basis to determine the progress of potential learners as well as teachers' reflection for the success or failure of learning.

Here the writer would like to present an example of possible speaking activities that could help the students to explore their intelligences, talents and to learn the presented material in an interesting way.

Pre activity:

Students tell the class if they had a part-time job or an experience of looking for a job. (intrapersonal)

Students think about humans' need in life, and why they need to have a job. (existentialist) 


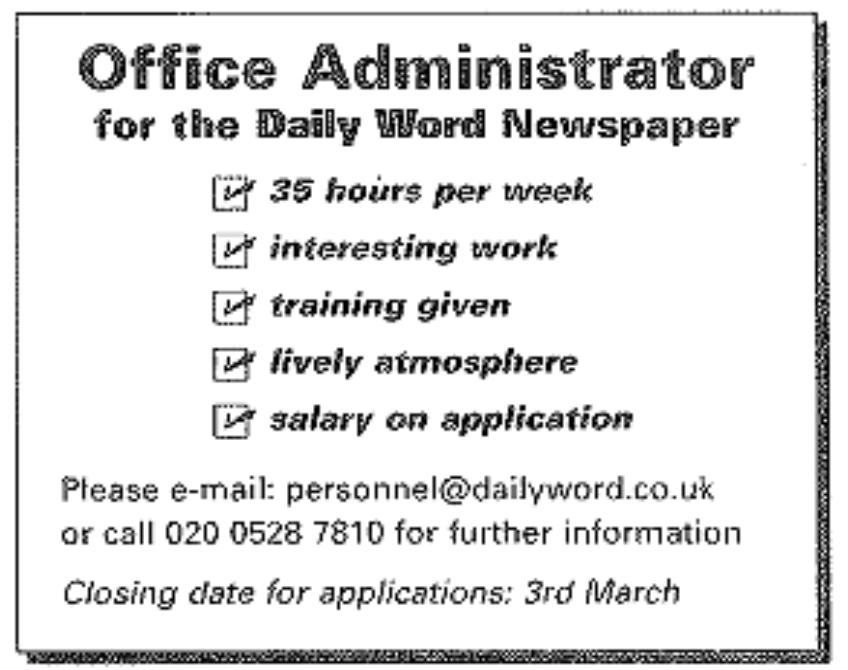

Picture 1. Job Advertisement (taken from the textbook Role plays for Today by Jason Anderson)

Students look at the job advertisement ads, and tell who might need the job and what qualifications are required. (intrapersonal)

Students think about the purpose the job advertisement, and analyze how the phrases are constructed. (verbal-linguistic)

Whilst Activity:

Students look at the job advertisement which contains basic details about the job. If they were interested in the job, what else would they want to know? They should write five questions.

Role play 1 . Phoning for a job interview. (interpersonal, bodily-kinesthetic, logical mathematical, musical)

Students are going to role play a job interview. One that acts as job applicants phone up the Human Resource Development Manager to find out more about office administrator job. He asks all the questions prepared and try to arrange a job interview if it sounds fine. He is also to jot down the time, date, and address of the office. When they have finished, they should swap roles and start again.

- In pairs, students discuss their monthly living cost and calculate what salary to expect. (logical mathematical)

Role play 2: (interpersonal, intrapersonal, bodily-kinesthetic, logical mathematical, musical, verbal)

Students are to create and role play the following scenes. They can also modify each of the scenes according to their creativity. The role play involves students acting as: job seeker, close friend, human resource development manager, and interviewer.

Scene 1. A friend of yours is unemployed and is looking for a job. He consults and shares his problems to you. You motivate and give him solution. 
Scene 2. One of you calls the company to ask for more information and the requirements needed. Two students act as a receptionist and a job-seeker.

Scene 3. You and your friend search the interview location by checking it in the Google map, draw the possible interview setting, and learn body language in the interview.

Scene 4. Interview time:

In the post speaking phase, again the teacher is suggested to give students different types of activities to check understanding.

- Hypothesize the possibilities of the job applicants to be accepted. (logicalmathematical, verbal)

- Draft an ideal interview setting including room and all the properties, and note down all the functions of each object. (spatial)

In the brackets the writer introduces the intelligence types for whom the activity would probably be most suitable. Although there might already be ready-made books for developing multiple intelligences (extension activities), by using this example writer intends to demonstrate many possibilities every teacher could create in the classroom speaking activities.

\section{CONCLUSION}

Basically, students have their own characteristics of potentials. Students' potential will not be useful if they are not well developed. In language learning, the provision of proper activities can be done to optimize it. Competence will be achieved by developing students intelligences, and empowering their potentials to grow by facilitating them with Multiple Intelligences-based activities. Appropriate learning activities will help them achieve the competence and capitalise their potentials into useful intelligence. Furthermore, the Multiple Intelligences activities also promote learner-centeredness in a language classroom and emphasize students' strengths and needs that will eventually benefit them.

\section{REFERENCES}

Akbari, R., \& Hosseini, K. 2007. Multiple intelligences and language learning strategies: Investigation possible relations. System, 36, 141-155

Armstrong, Thomas. 2002. Setiap Anak Cerdas. Jakarta: Penerbit PT Gramedia Pustaka Umum.

Fajar. (n.d.). Kecerdasan Ganda.Yogyakarta: PPPPTK Matematika.

Gardner, H. 2006. Multiple Intelligence: New Horison Teori and Practice. New York: Basic Book.

Ibragimova, N. 2011. Multiple Intelligences Theory in Action in EFL Classes: A Case Study. Eastern Mediterranean University. Gazimağusa, North Cyprus

Muslich, Masnur. 2011. Pendidikan Karakter Menjawab Tantangan Krisis Multidimensional. Jakarta: Bumi Aksara.

Mulyadi, Seto. 2002. Mempersiapkan Anak Unggul Milenium Ke-3 (Kompas Cyber Media).

Trianto. 2011. Desain Pengembangan Pembelajaran Tematik Bagi Anak Usia Dini Kelas Awal SD/MI. Jakarta: KENCANA. 